\title{
Marginal Fracture Toughness of Composite Resins
}

\author{
Yoshiaki TANI \\ Department of Dental Materials, Research Center for Medical Polymers and Biomaterials, Kyoto University, \\ Sakyo-ku, Kyoto 606, Japan
}

Received on September 23, 1982

The marginal fracture toughness of several types of composite resins was determined by means of the rattler test. Microparticle-filled resins showed significantly higher marginal fracture toughness than conventional composites. Posterior restorative composites were intermediate between MFRs and conventional composites. Amalgams were inferior to restorative resins. These data correspond with the clinical findings of restorative materials.

Key Words: Fracture Toughness, Composite Resin, Mechanical Property

\section{INTRODUCTION}

No one can deny the fact that progress in the field of composite restorative materials has greatly contributed to clinical dentistry. In conjunction with acid etching technics, composite resins have become popular materials for restoration of fractured incisors (Class IV restoration) and even for posterior teeth (Class I and Class II restorations).

Adequate wear resistance and marginal fracture toughness are important requirement for both anterior and posterior restorations. Increasing interest is being shown in the assessment of wear resistance of composite resins. ${ }^{1 \sim 3)}$ However, no effective method for the determination of marginal fracture toughness has yet been found.

The purpose of the present investigation was to determine the marginal fracture toughness of several types of composite resins by means of the rattler test.

\section{MATERIALS AND METHODS}

Materials used in this study consisted of fourteen conventional composites, four microparticle-filled resins, four visible light-cured composites, and four posterior restorative composites. An unfilled MMA and two types of amalgams were employed as controls. (Table 1)

Five specimens $(6 \times 6 \times 3 \mathrm{~mm})$ of each material were prepared and kept in a desiccator until they attained a constant weight. (Figures 1 and 2). The rattler test ${ }^{4)}$, one of the MPIF Standard Tests, is frequently employed to assess the edge stability of the green compact in powder metallurgy. (Figure 3) Five specimens were put in the cylindrical screen cage of the device* ( $9 \mathrm{~cm}$ in diameter; 14 mesh bronze net) and the cage was revolved 10,000 times at 87 r.p.m.. (Figures 4 and 5) The rate of the weight loss (S) of each material was calculated, after weighing every 1,000 times, by the following formula:

* Rattler Tester, Fukuda Machine Co., Kyoto, Japan 
Table 1 Materials tested

\begin{tabular}{|c|c|}
\hline Material (Manufacturer) & Batch Number \\
\hline \multicolumn{2}{|l|}{ Conventional Composites } \\
\hline Adaptic (Johnson \& Johnson) & Uni. 6k032, Cat. 61024 \\
\hline Adaptic Radiopaque (Johnson \& Johnson) & Uni. $8 \mathrm{j} 110$, Cat. $8 \mathrm{k} 110$ \\
\hline Clearfil F (Kuraray) & Uni. CU1234, Cat. CC1131 \\
\hline Clearfil F II (Kuraray) & Uni. FU217, Cat. FC117 \\
\hline Clearfil SC (Kuraray) & Uni. SU204, Cat. SC102B \\
\hline Compocap (Vivadent) & 50702 \\
\hline Concise $(3 \mathrm{M})$ & Uni. 1B6, Cat. $1 \mathrm{C} 6$ \\
\hline Cosmic (Amalgamated Dental) & Uni. UD1UE, Cat. UC22UE \\
\hline Miradapt (Johnson \& Johnson) & Uni. 9F902, Cat. 9F902 \\
\hline Prestige (Lee Pharmaceuticals) & Uni. HPR0124E, Cat. HPR0125E \\
\hline Prestige Plus (Lee Pharmaceuticals) & Uni. 1071, Cat. 1068 \\
\hline Profile (S.S. White) & Uni. 6843-17104, Cat. 6843-17108 \\
\hline Restodent (Lee Pharmaceuticals) & Pow. 0108, Liq. 0126 \\
\hline Spectra Bond (Den-Mat) & Uni. 490008, Cat. 410062 \\
\hline \multicolumn{2}{|l|}{ Microparticle Filled Resins } \\
\hline Isopast (Vivadent) & Uni. 520 679, Cat. 560579 \\
\hline Microrest - Cyringe Type- (GC) & Uni. 260211, Cat. FR 1-1 \\
\hline Superlux (DMG) & Uni. 90973, Cat. 90914 \\
\hline Silar (3M) & Uni. 8601A013, Cat. 8601B0JKL \\
\hline \multicolumn{2}{|l|}{ Visible Light-cured Composites } \\
\hline Fotofil (Johnson \& Johnson) & $8 \mathrm{~K} 832$ \\
\hline Plurafil Super (Lithema) & 00985 \\
\hline Superlux Daylight (DMG-Shofu) & 01099 \\
\hline Visio-Dispers (ESPE) & 42051 \\
\hline \multicolumn{2}{|l|}{ Posterior Restorative Composites } \\
\hline Microrest —Jar Type- (GC) & Uni. 140411, Cat. 160411 \\
\hline Clearfil Posterior (Kuraray) & Uni. PU-206, Cat. PC-106 \\
\hline Bellfirm P (Kanebo) & Uni. 81-0263, Cat. 81-0263 \\
\hline P-10 (3M) & Paste A 153, Paste B 169 \\
\hline \multicolumn{2}{|l|}{ Unfilled MMA } \\
\hline Sevriton (Amalgamated Dental) & Pow. LF 25, Liq. BN WG 2WL \\
\hline \multicolumn{2}{|l|}{ Fine-cut Alloy Amalgam } \\
\hline Luna Alloy (GC) & AM21 \\
\hline \multicolumn{2}{|l|}{ High-copper Alloy Amalgam } \\
\hline Spherical-D (Shofu) & 017607 \\
\hline
\end{tabular}

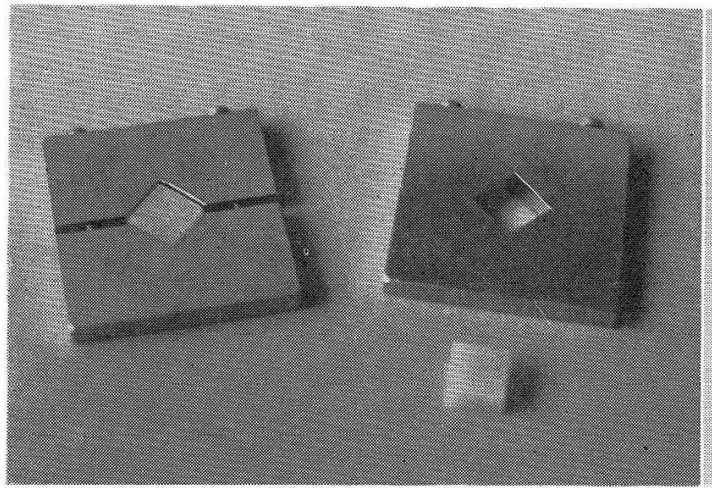

Figure 1 Stainless steel molds and specimens

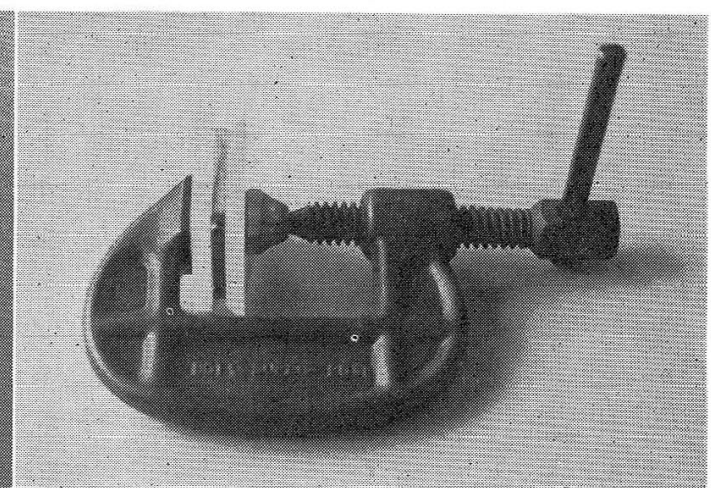

Figure 2 Preparing of the specimen 


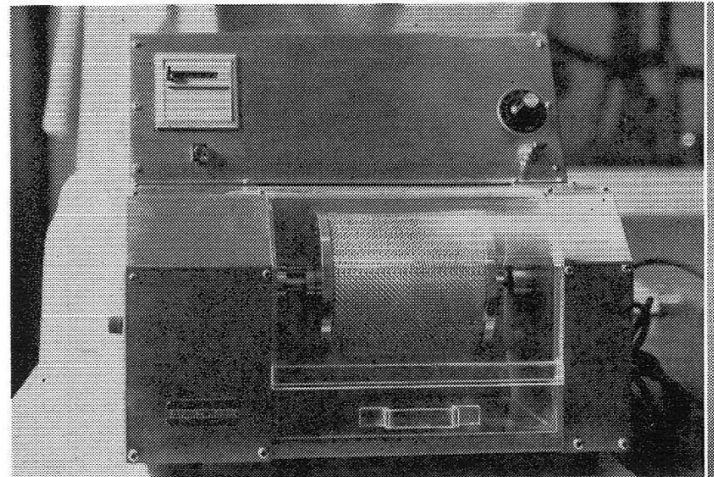

Figure 3 Rattler tester

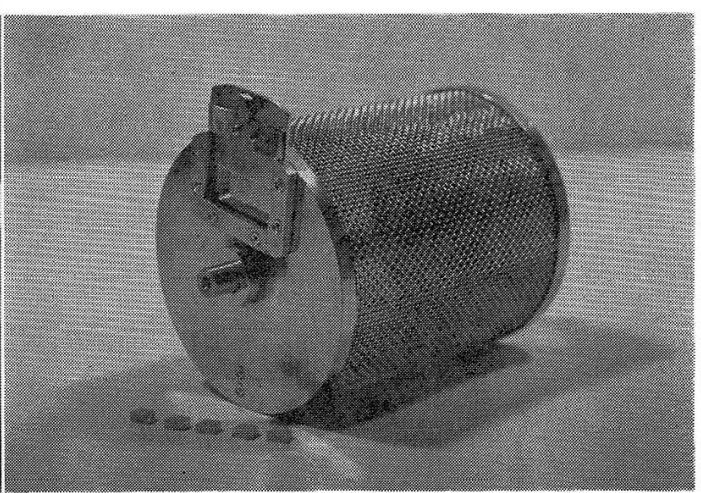

Figure 4 Cylindrical screen cage

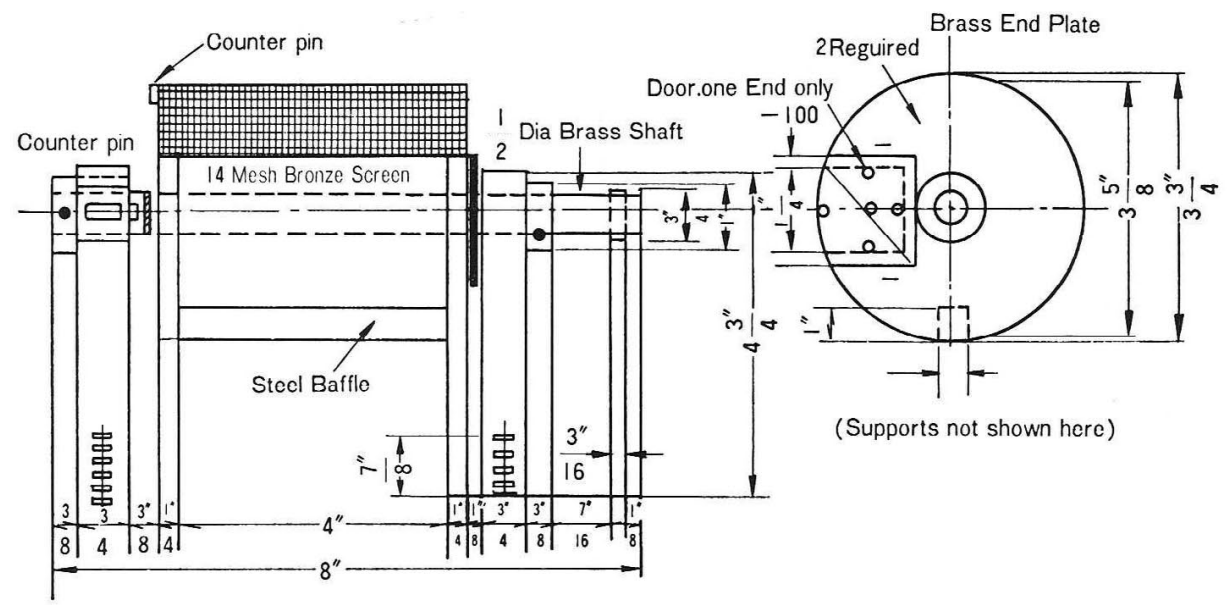

Figure 5 Specifications of the screen cage and shaft of the Rattler tester

$$
\mathrm{S}=\frac{\mathrm{A}-\mathrm{B}}{\mathrm{A}} \times 100(\%)
$$

where $\mathrm{A}$ is sum of the weight losses of five specimens before the test, and B is sum of their weight losses after the test.

The rate is represented as the marginal fracture toughness in accordance with the edge brittleness of restorative materials. In addition, the surfaces of chipped specimens were examined by scanning electron microscopy after the test.

\section{RESULTS AND DISCUSSION}

Figures $6 \sim 13$ show the results of the rattler test of several types of restorative resins. These results showed significantly higher marginal fracture toughness for microfilled composites than for the conventional composites. With the microfilled composites, the increase in weight loss stopped after 5,000 or 6,000 revolutions, whereas the weight loss of the conventional composite continued to increase in proportion to the number of revolutions. The fact that the weight loss of materials composed of large size fillers (such as Adaptic or Clearfil F) was larger than that of materials composed of small size fillers ${ }^{5)}$ (such as Restodent or Clearfil F II) suggests that marginal fracture toughness is influenced by filler particle size. 

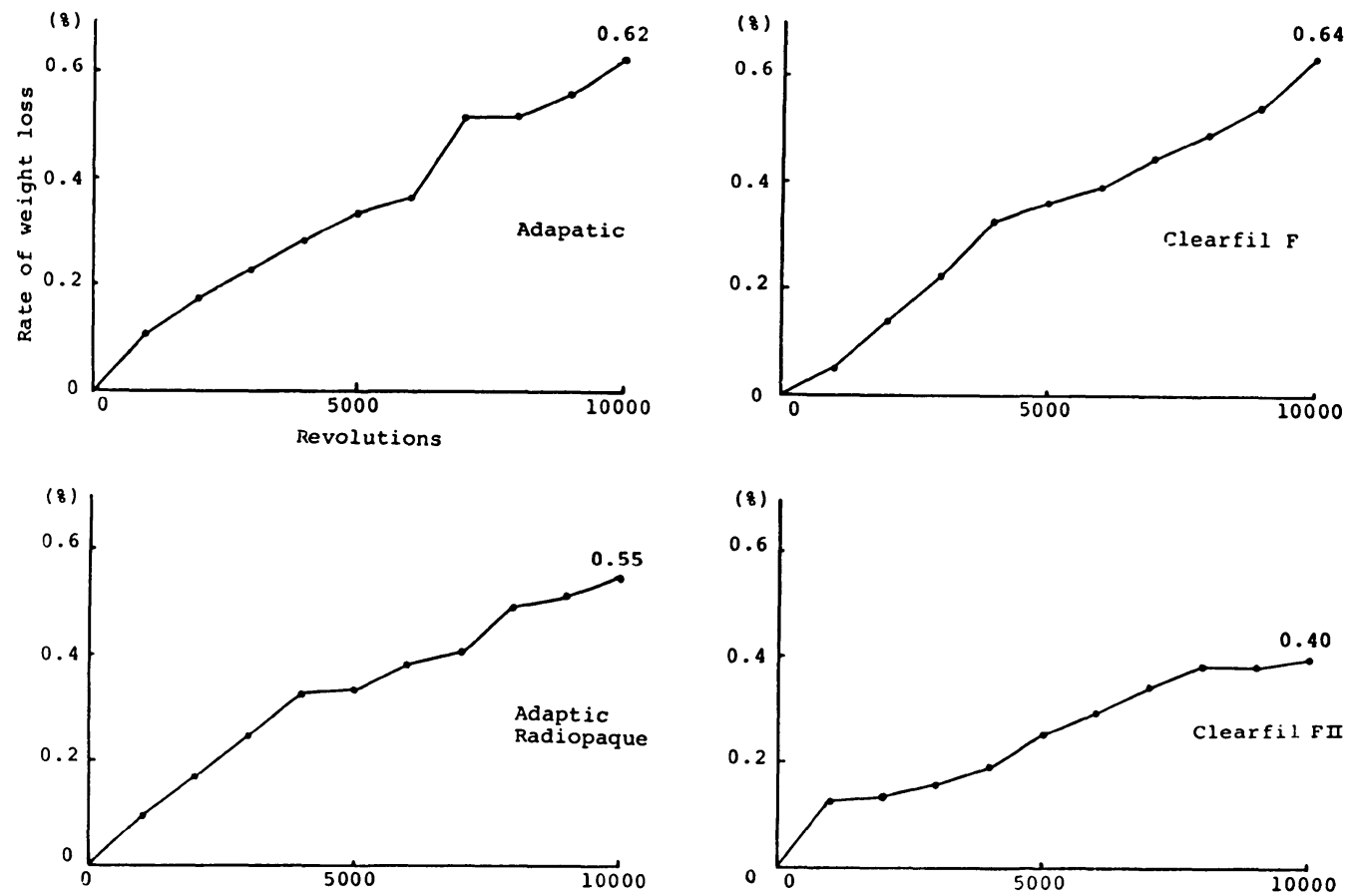

Figure 6 The rate of accumulated weight losses of regular composite resins (1)
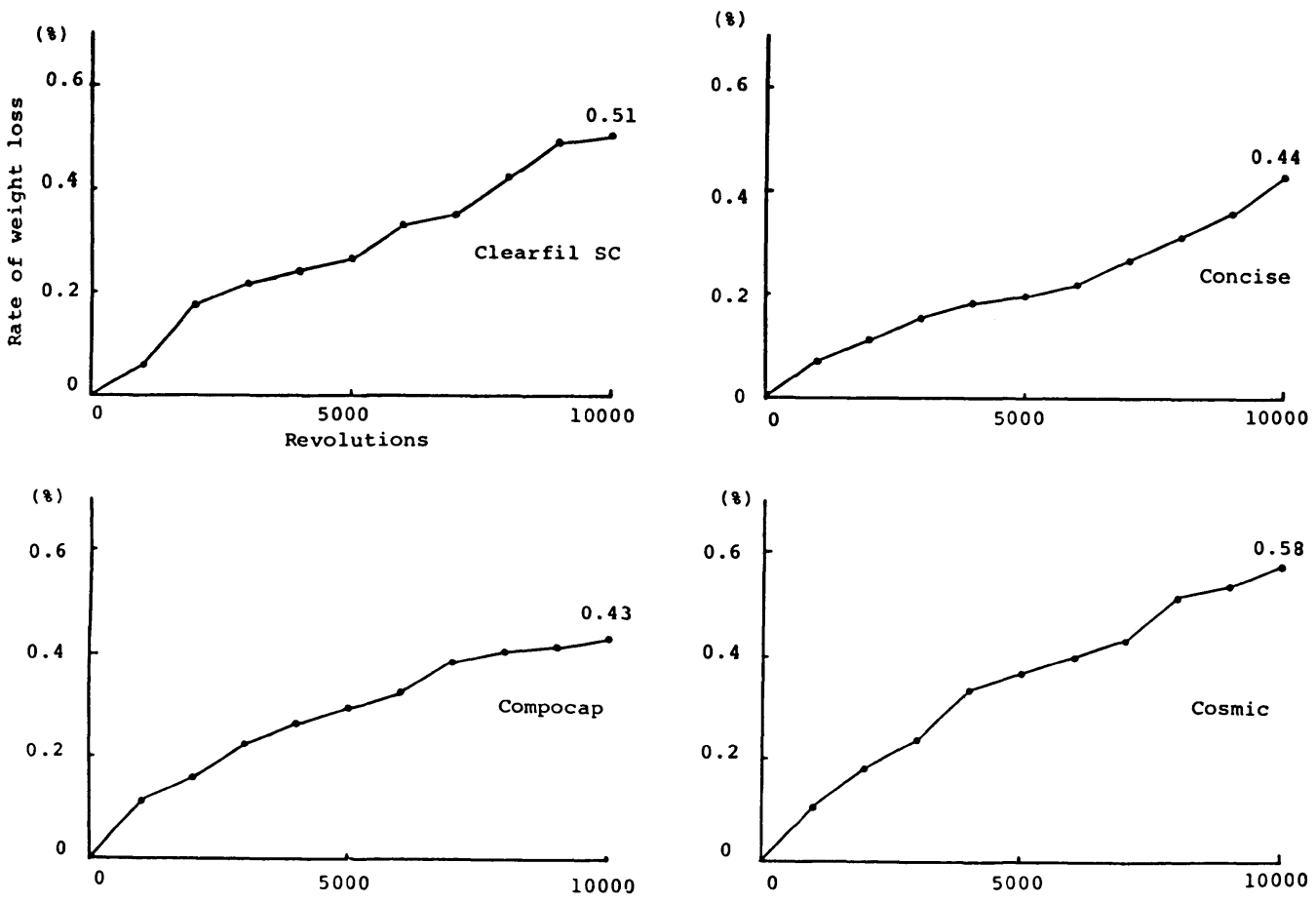

Figure 7 The rate of accumulated weight losses of regular composite resins (2) 

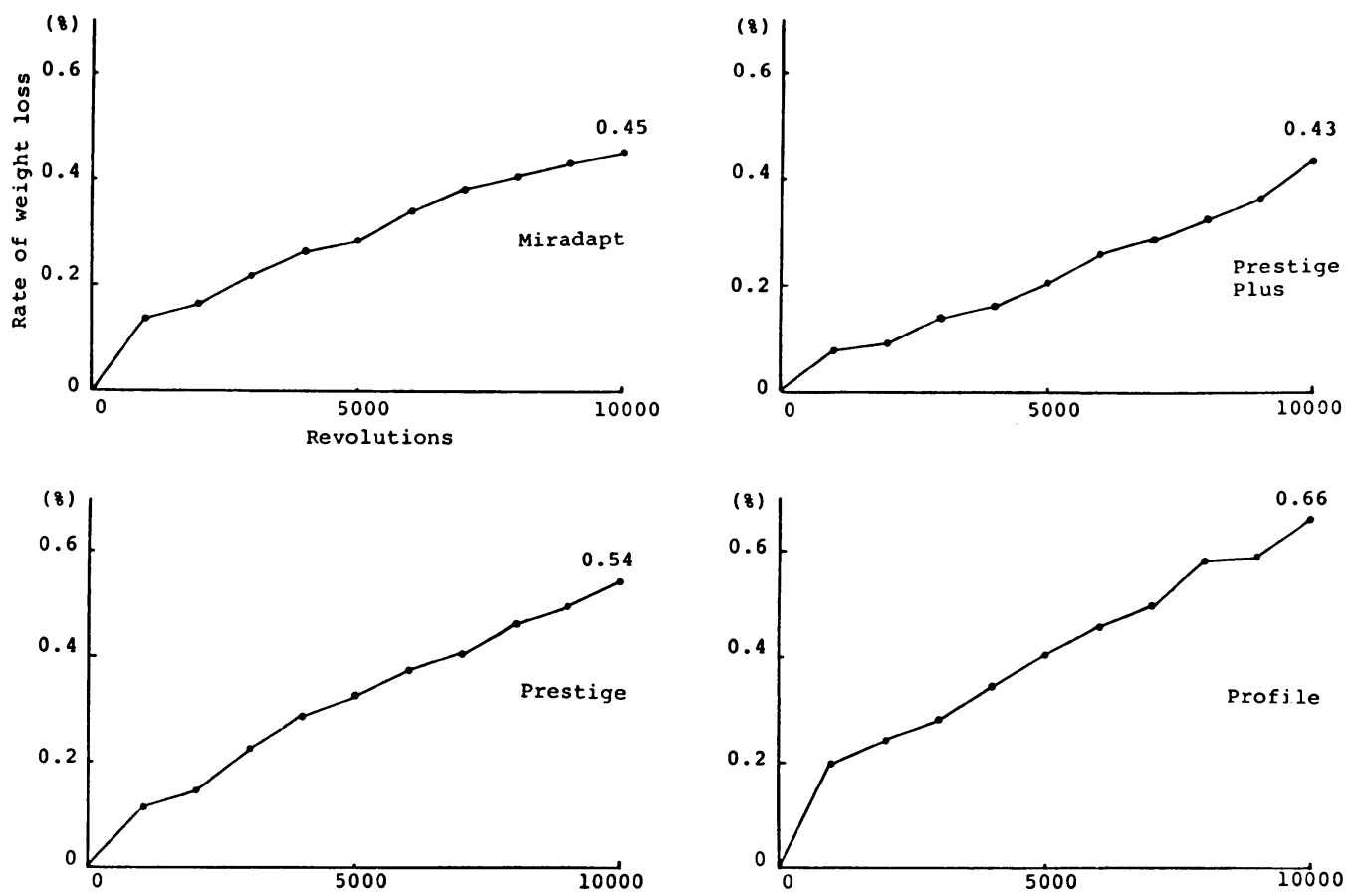

Figure 8 The rate of accumulated weight losses of regular composite resins (3)
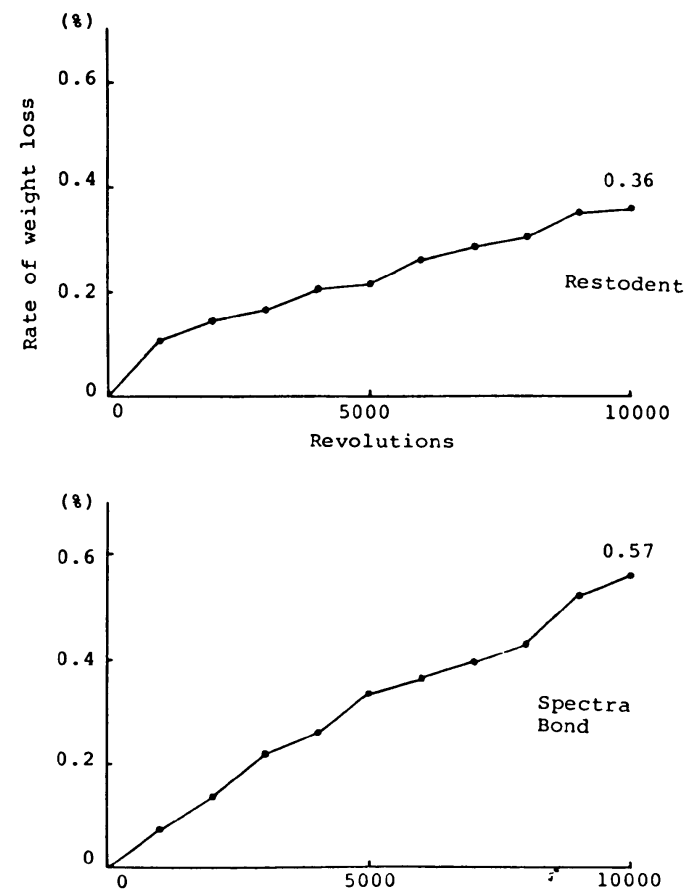

Figure 9 The rate of accumulated weight losses of regular composite resins (4) 

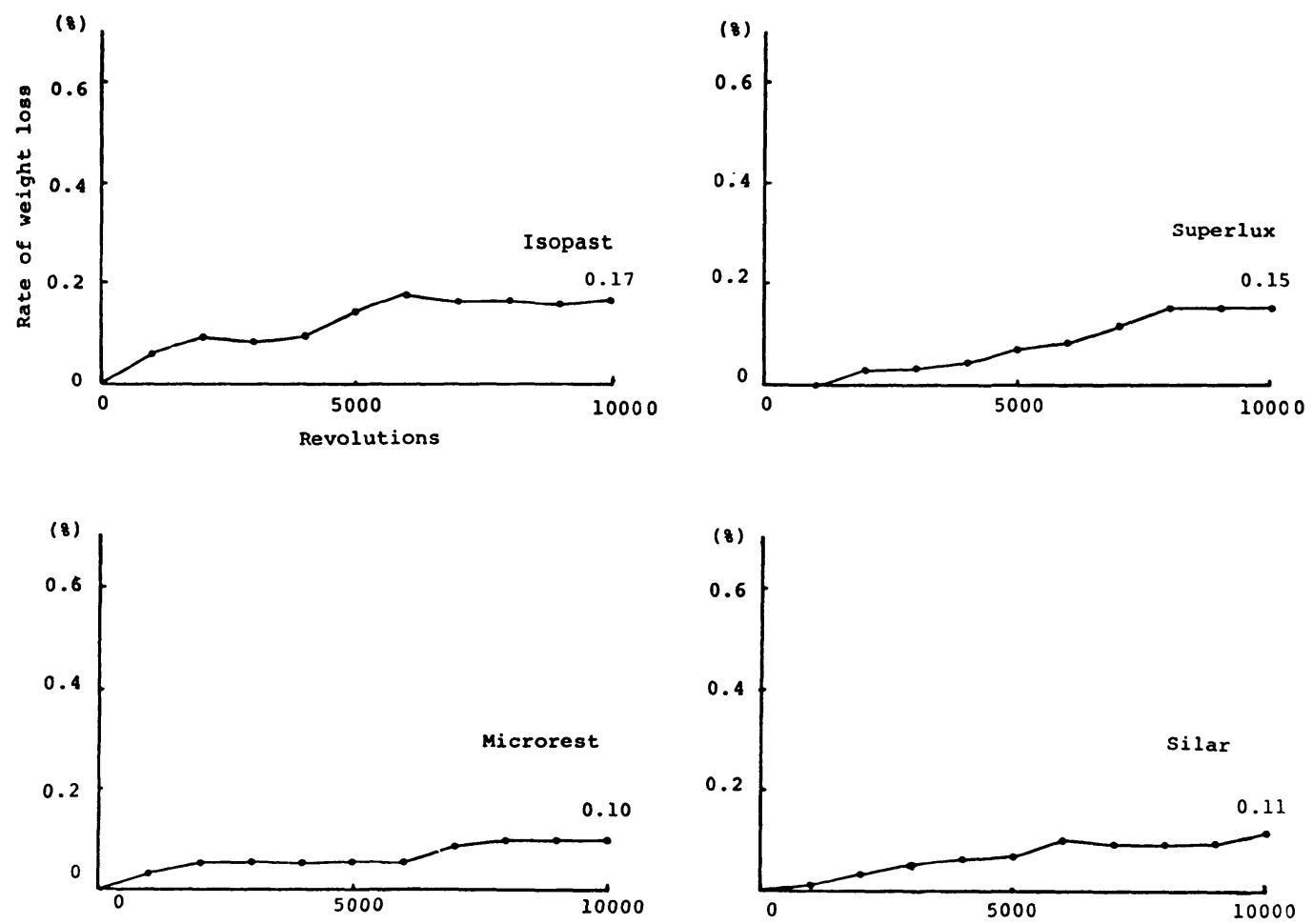

Figure 10 The rate of accumulated weight losses of microparticle-filled resins
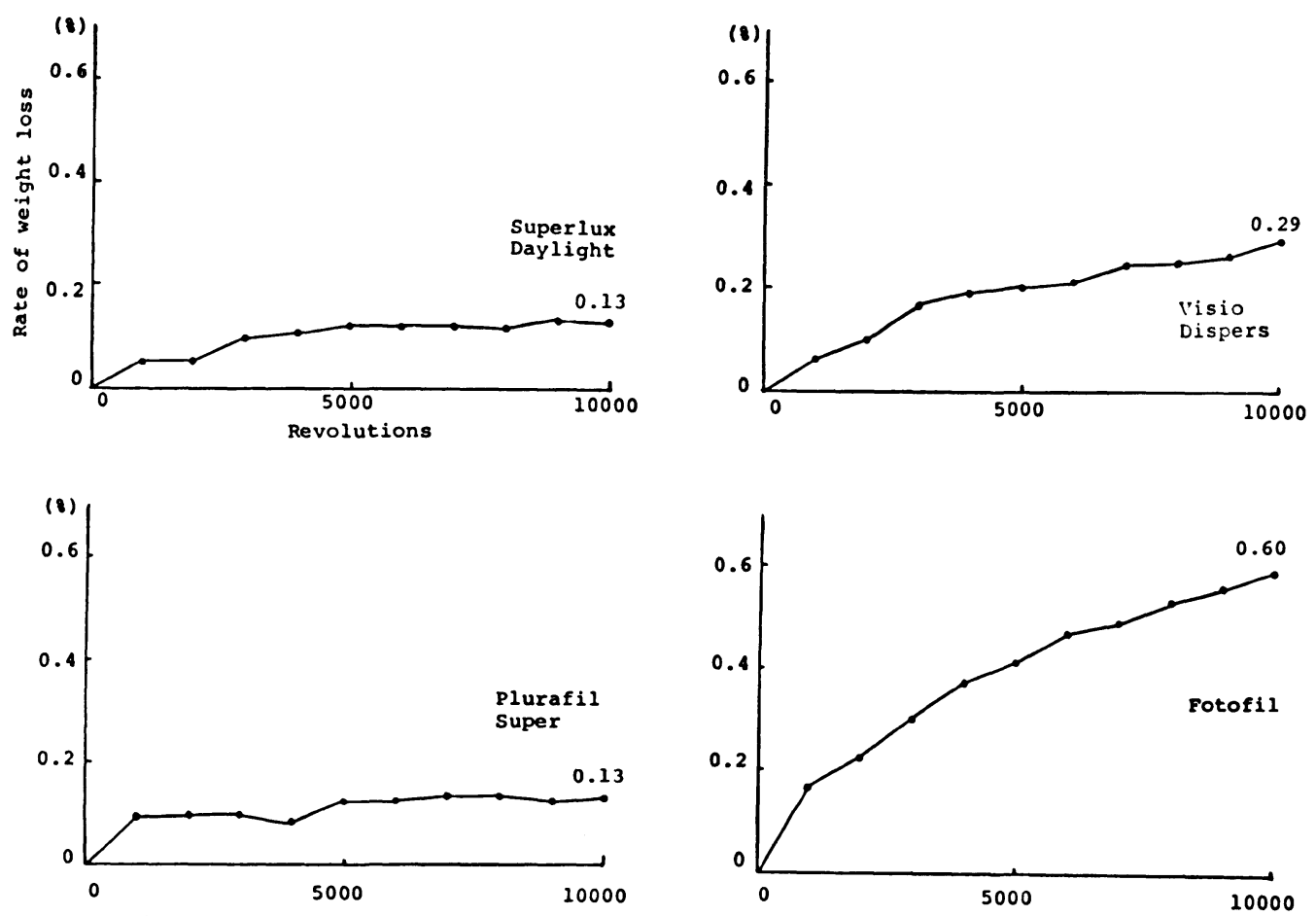

Figure 11 The rate of accumulated weight losses of visible light-cured composite resins 

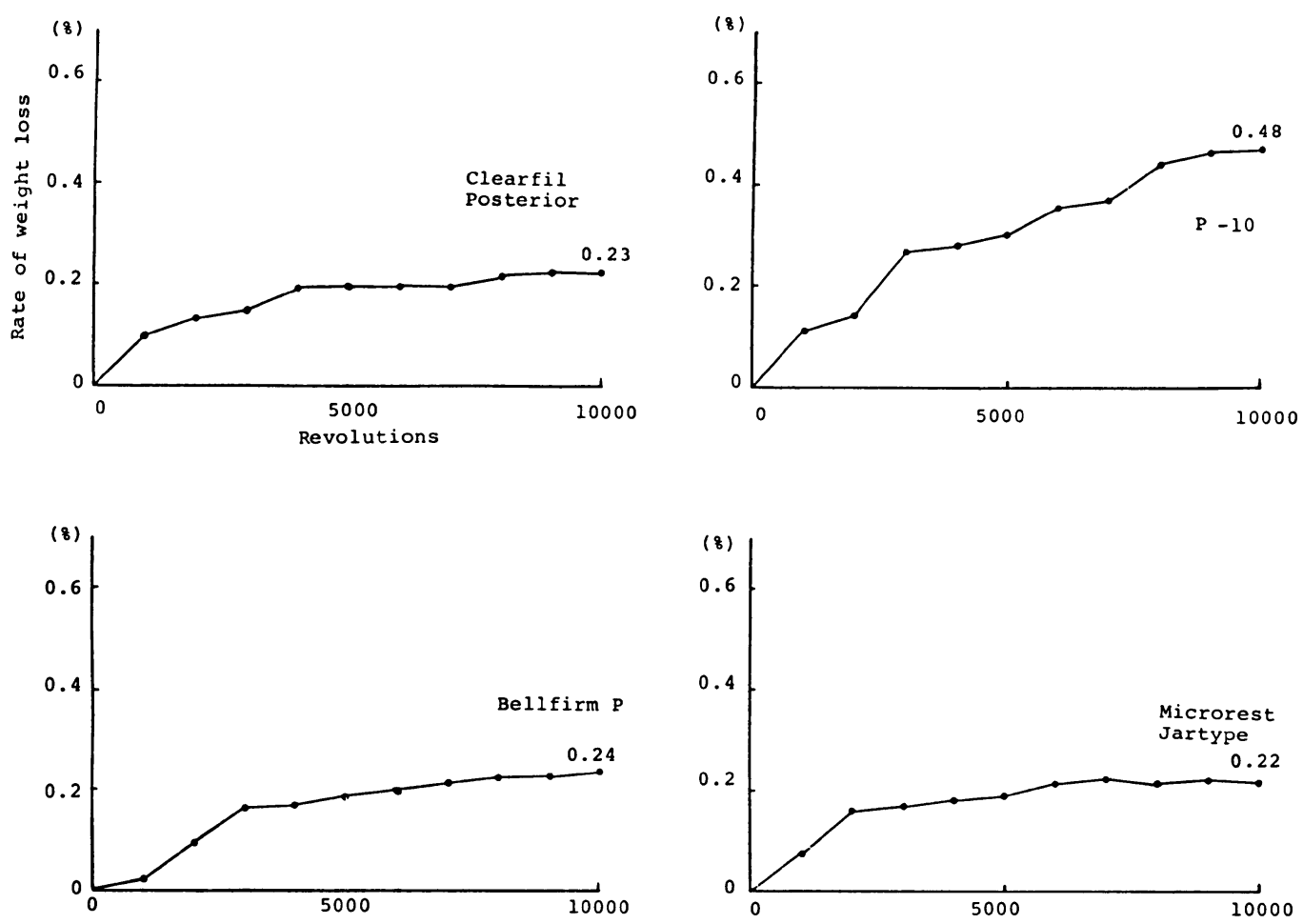

Figure 12 The rate of accumulated weight losses of posterior restorative composite resins

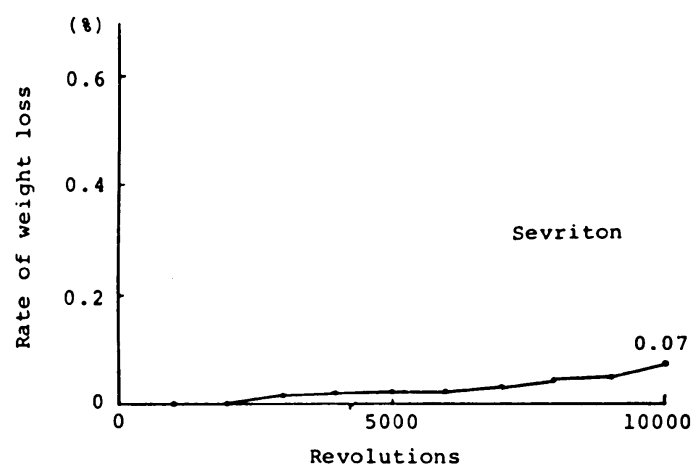

Figure 13 The rate of accumulated weight loss of an unfilled M.M.A. resin

Posterior restorative composites were intermediate between microfilled and conventional composites in terms of mariginal fracture toughness.

Figure 14 shows the results of the rattler test for two types of amalgams. The marginal fracture toughness of the fine-cut alloy amalgam was far less than that of the high-copper amalgam. Both of the amalgams were far lower in marginal fracture toughness than all the restotative resins tested. These data correspond with the property of amalyams known as "ditching" which occurs readily at the margin of the amalgam restoration ${ }^{6}$.

The rate of volume loss was comparable to that of weight loss for every material tested. 


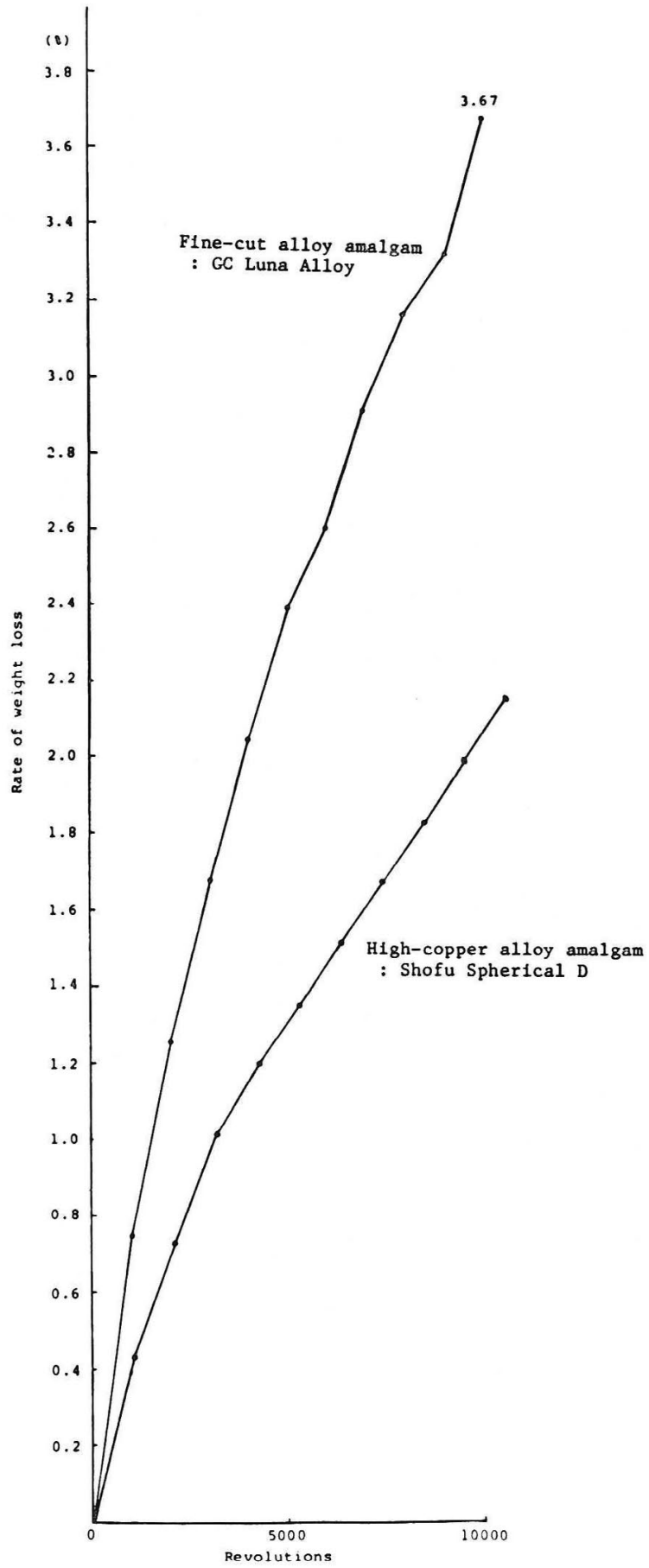

Figure 14 The rate of accumulated weight losses of amalgams 


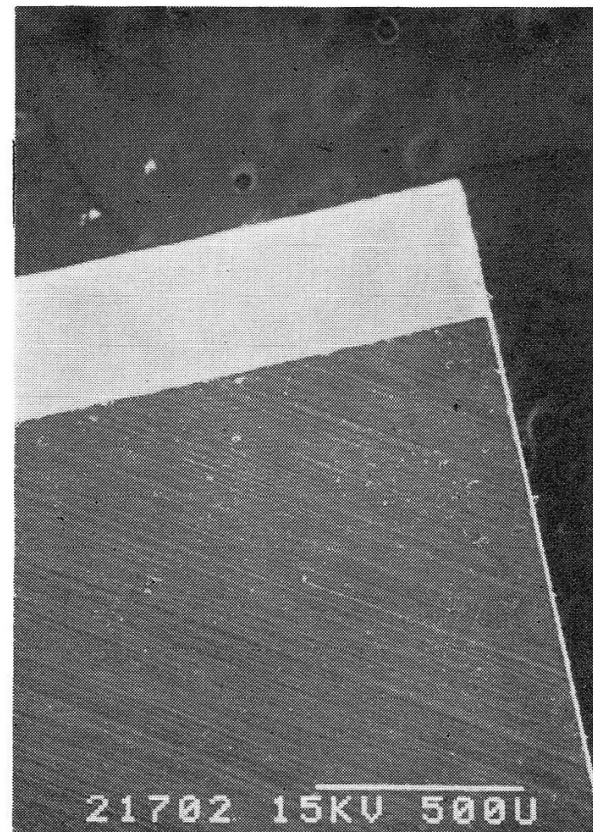

$\times 50$

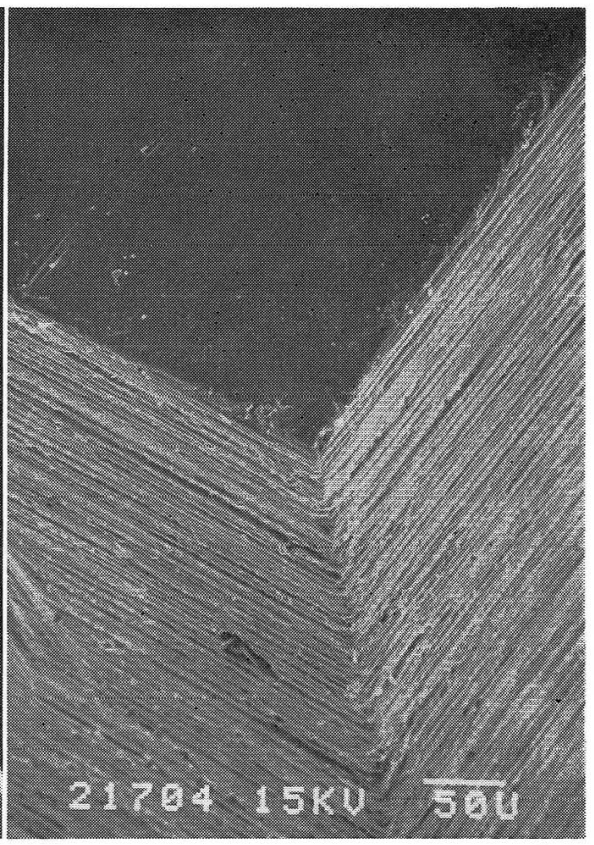

$\times 200$

Figure 15 SEM views of specimen before testing (Silar)

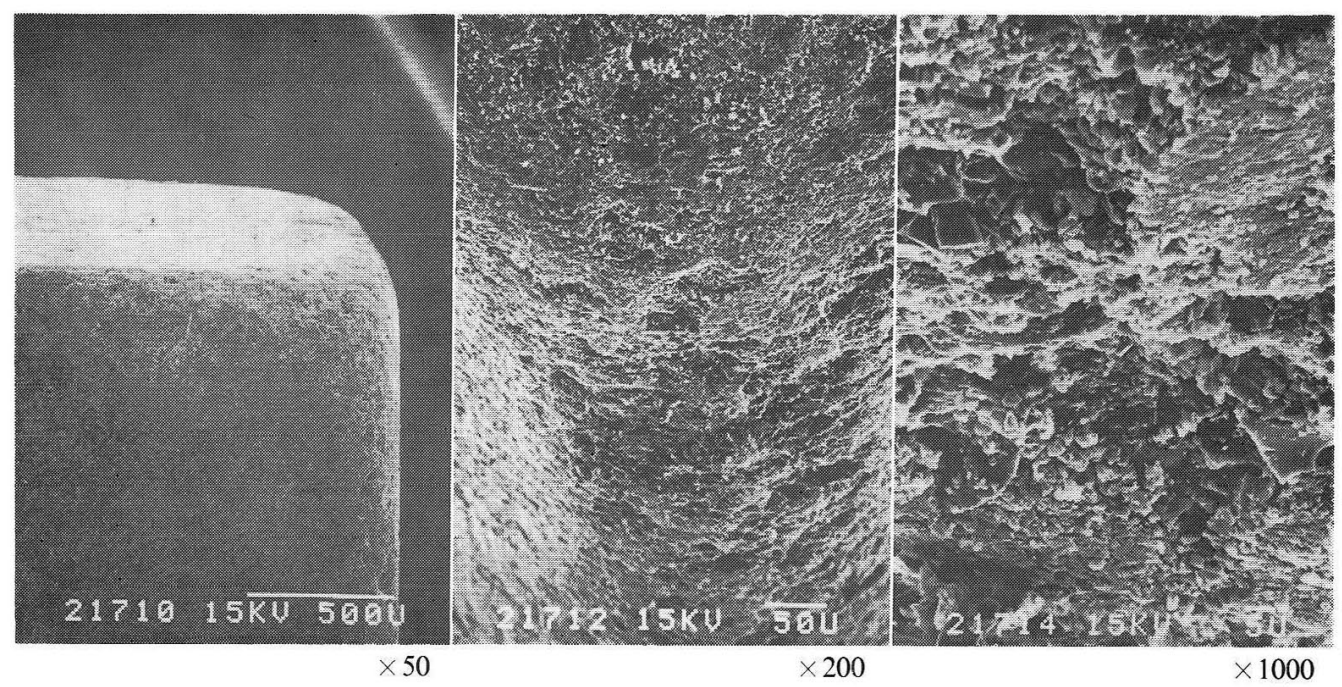

Figure 16 SEM Views of Adaptic specimen after testing

Figure 15 shows a SEM photograph of the specimen before testing, and Figures $16 \sim 19$ are representative SEM photographs of the materials after testing. These results in combination with the SEM studies suggest that the bonding at the filler-matrix interface of regular composites is more unstable than that of microfilled composites. 


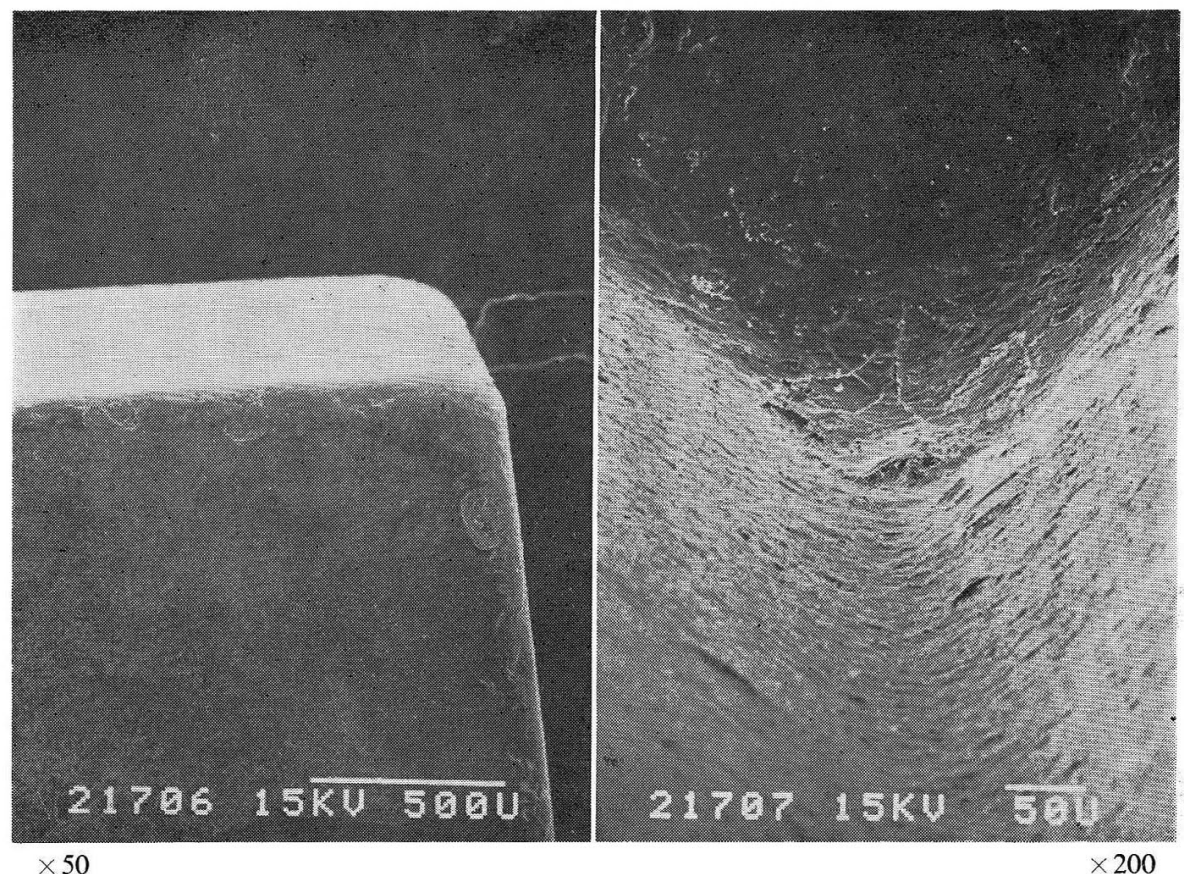

Figure 17 SEM Views of Silar specimen after testing

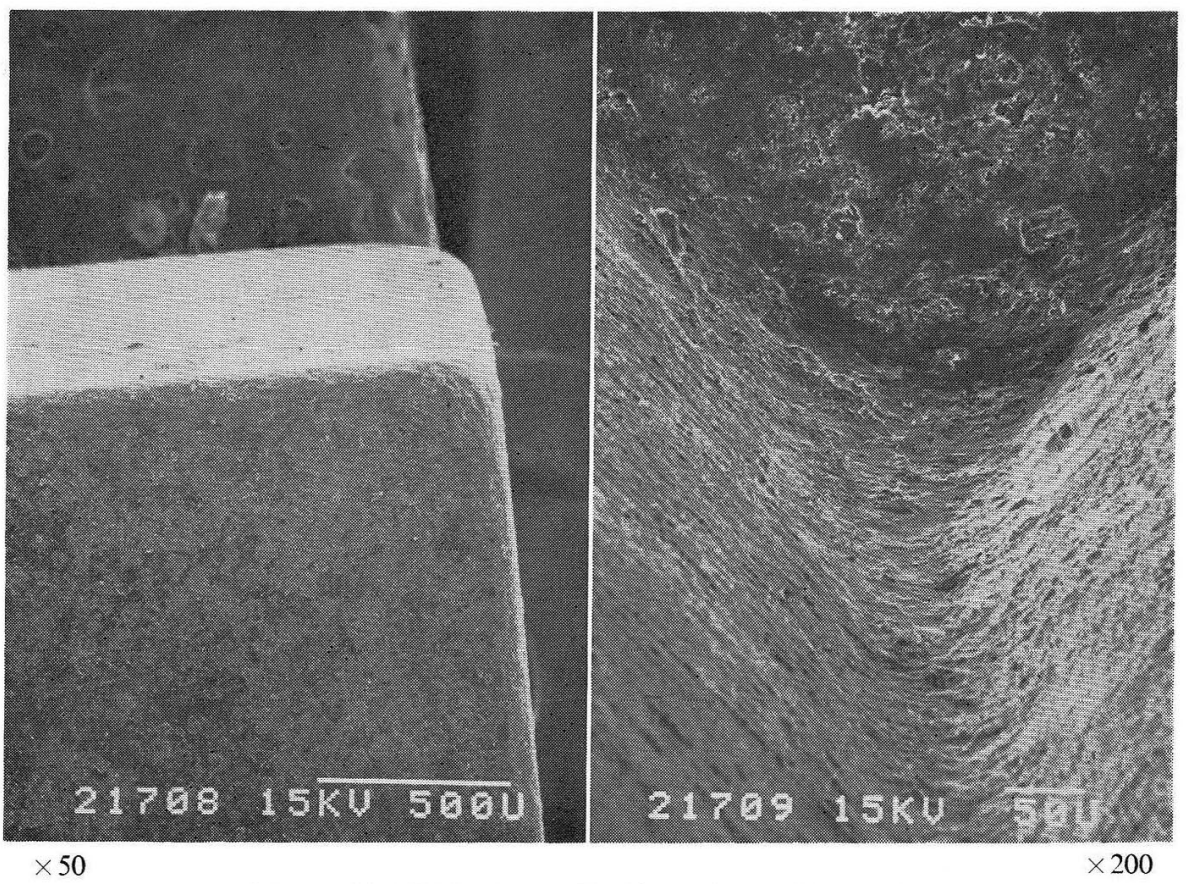

Figurc 18 SEM Vicws of P-10 specimen after testing 


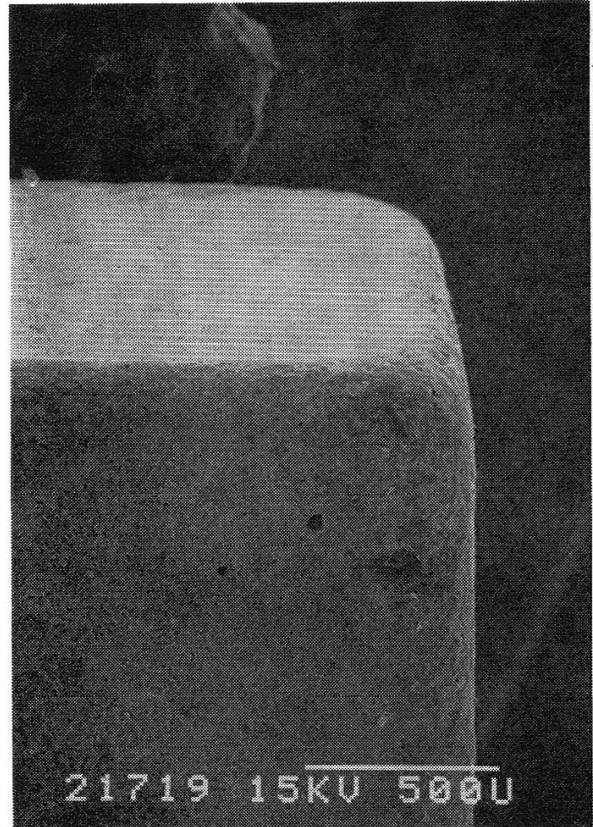

$\times 50$

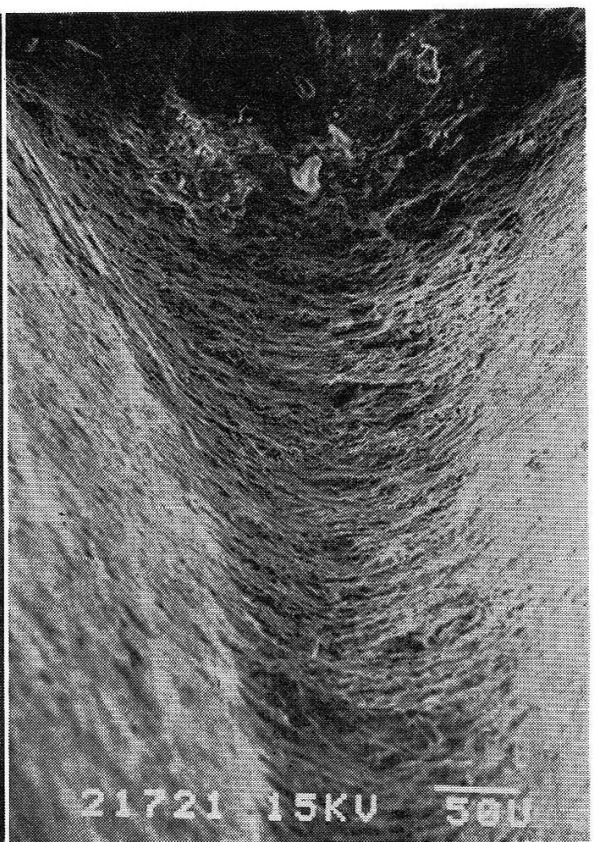

$\times 200$

Figure 19 SEM Views of Sevriton specimen after testing

\section{CONCLUSION}

1. The results of the rattler test indicated significantly higher marginal fracture toughness for microfilled composites than for conventional composites.

2. With microfilled composites, the increase in weight loss stopped after 5,000 or 6,000 revolutions, whereas the weight loss of conventional composites continued to increase in proportion to the number of revolutions.

3. The posterior restorative composites were intermediate between microfilled and conventional composites in terms of marginal fracture toughness.

4. The marginal fracture toughness of amalgams was far lower than that of restorative resins.

\section{REFERENCES}

1) Kusy, R.P. and Leinfelder, K.F.: Pattern of wear in posterior composite restorations, J. Dent. Res., 56: 544, 1977.

2) Derand, T. and Enrnford, L.: A long-term evaluation of abrasion of dental composite resins, J. Dent. Res., 59: 721-723, 1980.

3) McCabe, J.F. and Smith, B.H.: A method for measuring the wear of restorative materials in vitro, Brit. Dent. J., 151: 123-126, 1981.

4) M.P.A. Standard, 15-51T, 1951.

5) Tani, Y.: Improvements and clinical considerations of composite resins, Dental Outlook, 55: 215224, 1980, (in Japanese)

6) Phyllips, R.W., Avery, D.R., Mehra, R., Swartz, M.L. and McCune, R.J.: One-year observations on a composite resin for Class II restorations, J. Prosthet. Dent., 26: 68-77, 1971. 


\title{
本号掲載論文の和文抄録
}

\author{
Cupt の規則化に及ぼす冷却速度の影響 \\ 久恒邦博*, 太田道雄, 山根正次 \\ 九州大学歯学部歯科理工学講座 \\ *現在 : 長崎大学歯学部歯科理工学講座
}

等原子比合金 $\mathrm{CuPt}$ の規則化について, 臨界温度以上 $\left(900^{\circ} \mathrm{C}\right)$ から室温まで種々の速度で冷却した場合の影響 を電気抵抗測定, 硬さ試験, X線回折, 透過型電子顕微 鏡により検討した。水中冷却した武料は完全な不規則相 （f $\mathrm{fc}_{\mathbf{c c}}$ )であったが, 空冷した試料は冷却中にかなりの則

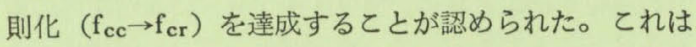

過剩空孔の消費に伴なう規則化である。冷却速度が遅く なるにつれて規則度は上昇し， $-25^{\circ} \mathrm{C} / \mathrm{min}$ 以下におい ては完全な規則状態が得られた。規則化による硬化の寄 与は中間の泠却速度である空冷武料でピークが認められ た。この硬さピークに対応する規則化は粒内におけるマ イクロドメインの形成に起因する均一反応であった。

マグネンア系埋没材による純チタンおよびチタン合金の歯科鋳造について

井田一夫*, 都賀谷紀宏*, 堤 定美*, 竹内正敏*

*京都大学医用高分子研究センター歯科材料応用研究部門

純チタンおよびチタンを主成分とする合金は，耐食性 や生体適合性が非常によいとと, 軽いとと,などの特徽 を有するので，歯科におけるクラウン・ブリッジ用，床 用，インプラント用などの材料として興味のある金属で ある。

しかし，融点が高いととや高温における反応性が大き いとと,などのために鋳造が極めて困難であり，てれま で歯科用金属として使用されていなかった。

本研究は, 新しい鋳造機 “CASTMATIC” を使用し, マグネシアを主成分とする埋没材を使用して純チタンお
よびチタン合金を鋳造し，鋳造物の機械的性質，表面性 状などを検討したものである。またマグネシア系埋没材 の物理的性質も検討した。

実験の結果，この方法で鋳造した純チタンは金合金 （硬質）に近い機械的性質を示し, 鋳肌のよいものが得 られた。またインプラント用ブレード, クラウン, ブ リッジなど臨床用のパターンにおいてあ外観のきれいな 鋳造体を得ることができた。しかし寸法精度については 更に検討が必要である。

\section{コンポシットレンジの marginal fracture toughness について}

谷 嘉明

京都大学医用高分子研究センター 歯科材料応用研究部門

歯科用修復材の縁端強度は臨床的に重要な性質である あのの，その測定法は確立されていない。本報では，粉 末治金工業の分野で，圧粉体の成形性を測定する規格試 験法として用いられている Rattler 陚験法を応用して, 各種コンポジットレジンの marginal fracture toughness を評価した。各材料について, $6 \times 6 \times 3 \mathrm{~mm}$ の角片 5 個 づつ作製し, Rattler 試験機の青銅金龬製シリンダー
ケージの中に入れ， 87 r.p.m の回転速度で 10,000回転さ せて, 試片の縁端部を磨滅させた。試験前の試片重量に 対する試験後の重量損失率を求めた。重量損失率の小さ いものほど marginal fracture toughness にすぐれてい ることになる。

実験の結果，MFR があっとあすぐれ，次いで日歯用 コンポジットレジンで, 従来型コンポジットレジンが 
あっとあ劣っていた。MFR では一定の回転数以上にな ると辺縁部の破折は起らなくなったが, 従来型コンポ ジットレジンでは破折が持続した。コンポジットレジン
の marginal fracture toughness は,フィラーの粒径や配 合率に影響をうりることがわかった。アマルガムはさら に著しい辺縁部の破折を示した。

\section{鋳造リング内の埋没材の硬化膨張, 水和膨張による MOD パターンの変形}

(第 1 報) 二次元光弾性実験による直接的観察と力学的解析

$$
\text { 大野弘機*, 宮川 修, 塩川延洋 }
$$

\section{新渴大学歯学部歯科理工学教室 $*$ 現在 : 東日本学園大学歯学部歯科理工学教室}

エポキシレジンで作製した MOD パターンを鋳造リ ング内に埋没し，二次元光弾性実験の等色線の観察をむ とに, 埋没材の硬化膨張, 水和澎張によって生じたパ ターンの変形について力学的解析を行った。

パターンの変形速度は, 埋没材の膨張速度に一致す る。支台歯部位の埋没材の膨張によって,パターンは近 逜心万向に開脚の変形を受ける。その結果, 咬合部位に 曲げモーメントと軸引張応力が作用する。また，変位の
大きい部分（函肉側のマージン，咬合部位と脚部の接合 部分）は，外周の埋没材壁に接するようになり，それぞ れの変位が拘束される。MOD インレーの支台雷への適 合を考える上で重要である畨肉側マージンの開脚による 変位を分解すると, 咬合部位の曲げと引張要素, それに 脚部のたわみ要素の 3 つになる。全変位量に対するそれ ぞれの割合は, $88 \%, 2 \%, 10 \%$ ある。

鋳造リング内の埋没材の硬化膨張, 水和膨張による MOD パターンの变形

(第 2 報) 変形飞およぼす $\mathrm{W} / \mathrm{P}$ ，リング内でのパターンの位置， アスベスの条件による影響

大野弘機*, 宮川 修, 塩川延洋

新潟大学歯学部歯科理工学教室 $*$ 現在 $:$ 東日本学園大学歯学部歯科理工学教室

エポキシレジンで作製した MOD パターンを鋳造リ ングに埋没し，二次元光弾性実験によって，埋没材の硬 化過程で生じたパターンの変形を钼察した。変形形態や 变形量におよぽす諸条件 (W/P，アスベストの有無，了 スベストの枚数および処理法, リング内でのパターンの 位置）の影響について検討した。

アスベスト無の場合, 膨張の発現に伴って徐々にパ ターンに圧縮応力が作用するととが観察された。パター ン外周と支台菌部の埋没材の両方の膨張が大きくなる条
件でのみ, 変形量は大きくなる。つまり, W/P が小さ くなると大きくなる。また，アスベストが 3 枚までは， 枚数の増加ととあに变形が大きくなるが, それ以上では 変形量は変わらない。柬肉側マージンをアスベストに近 づけて埋没すると変形は大きくなる。Dry アスベストが Wet アスベストより変形が大きい。

アスベスト無の場合を除いて，その他の条件では，変 形の形態は変わらない。 